Cite this: DOI:

10.1039/x0xx00000x

Received 00th January 2012,

Accepted 00th January 2012

DOI: $10.1039 / \times 0 \times x 00000 x$

www.rsc.org/

\title{
A New Approach Towards the Synthesis of Pseudaminic Acid Analogues
}

\author{
Matthew Zunk, ${ }^{a, b}$ James Williams, ${ }^{a, c}$ James Carter $^{a}$ and Milton J. Kiefel ${ }^{*}, a$
}

The pseudaminic acids are a family of 5,7-diamino-3,5,7,9-tetradeoxynonulosonic acids that are essential components of bacterial polysaccharides and glycoproteins. This paper describes our approach towards the synthesis of analogues of pseudaminic acid, and involves the efficient introduction of the requisite Nitrogen functionalities from a readily available precursor.

\section{Introduction}

Pseudaminic acid (Pse, $\mathbf{1})$ is a 9-carbon acidic carbohydrate that belongs to the family of sugars called nonulosonic acids. Other members of the nonulosonic acid family include the well-known sialic acids like $N$-acetylneuraminic acid (Neu5Ac, 2) and keto-deoxynonulsonic acid (KDN, 3). The sialic acids are a structurally diverse group of sugars, ${ }^{1-6}$ that have been extensively studied for their important role in biological and pathological processes, including microbial infection, and cancer. ${ }^{1,2,6-8}$ Interestingly, sialic acids have also been found in tissues such as fish eggs, and isolated from insects, and they are increasingly being discovered within pathogenic and non-pathogenic bacteria and archaeal organisms. ${ }^{2,4,5}$

The pseudaminic acids are 5,7-diamino-3,5,7,9-tetradeoxynonulosonic acids that have been recently identified and, along with legionaminic acid (Leg, 4), represent a new group of carbohydrates that appear to have an important role in microbial pathogenesis. ${ }^{910}$ First isolated in 1984 from the LPS of Pseudomonas aeruginosa and Shigella boydii, ${ }^{11}$ pseudaminic acid derivatives have subsequently been found in a number of bacterial glycans. ${ }^{9,10}$ Natural structural variation found in the pseudaminic acids to date are associated with the type of $N$-acyl substituent found at C-5 and C-7, with $\mathrm{N}$-acetimidoyl and $\mathrm{N}$-(3-hydroxybutanoyl) being commonly found modifications. For a detailed account of structural variations found in microorganisms, see reviews by Knirel, et al., ${ }^{9}$ and Zunk \& Kiefel. ${ }^{10}$

The presence of nonulosonic acids like Pse and Leg as components of bacterial glycans has attracted considerable attention over recent years. ${ }^{12-24}$ Of particular interest is the fact that opportunistic bacterial species often decorate their flagella or pili with sugars like Pse. Since these organisms use their flagella and pili to aid motility, which aids in colonisation, the presence of these nonulosonates can be considered a virulence factor in these bacteria. ${ }^{25,26}$ For example the gastrointestinal pathogens Campylobacter and Helicobacter demonstrate highly efficient flagellin motility under conditions of elevated viscosity such as that found in the gastric lumen. ${ }^{27}$ Studies have shown that although flagella are a major structural determinate for bacterial virulence, it is in fact the glycosylated ends of these flagella that facilitate bacterial host interactions and therefore largely confer immune responses. ${ }^{25,27}$ Therefore, whilst the exact biological function of both pseudaminic acid (1) and legionaminic acid (4) and their naturally occurring derivatives is not fully understood, ${ }^{26,28-30}$ it is known that the presence of these post-translational glycolytic modifications of flagellin subunits is absolutely necessary for the assembly of a functional flagellin. It has also been noted that due to the structural similarity of these bacterial nonulosonic acids to that of eukaryote sialic acids, this may contribute to bacterial virulence by dampening the immune response to invading bacterium that utilise these important carbohydrates. ${ }^{9,31}$

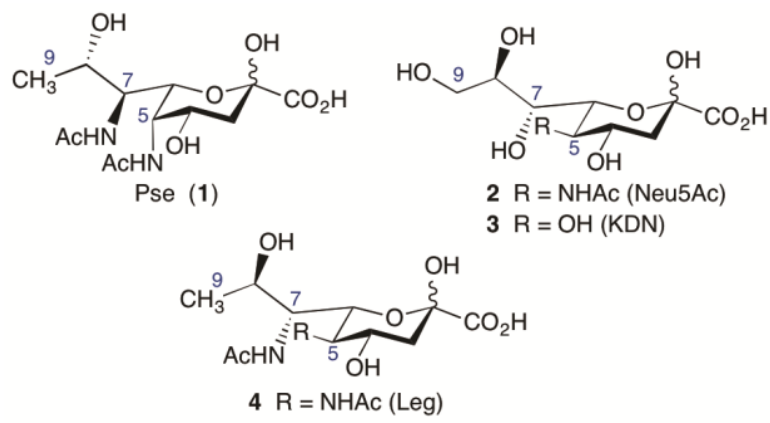

Figure 1 Examples of commonly occurring nonulosonic acids

Given the emerging interest in nonulosonic acids as potential bacterial virulence factors, it seems reasonable that in order to expand our understanding of the role of these carbohydrates we require the efficient synthesis of analogues and derivatives of Pse that could be utilised in studies investigating proteins or enzymes that utilise this carbohydrate. Previous syntheses of pseudaminic acids have relied on either chemoenzymic approaches using the natural pseudaminic acid enzymes, ${ }^{24,32,33}$ or chemical synthesis involving multi-step processes or poor yielding aldol condensations. ${ }^{15,16,34}$ We report here a novel approach from 
sialic acid that allows the efficient synthesis of a range of Pse related compounds.

\section{Results and Discussion}

When approaching the synthesis of pseudaminic acid derivatives like $\mathbf{1}$, we initially looked at commercially available precursors. Structurally, pseudaminic acids have an L-glycero-L-manno configuration, whilst the neuraminic acids are based around a D-glycero-D-galacto configuration. When comparing $\mathbf{1}$ to $\mathbf{2}$, it can be seen that for pseudaminic acid the functionality at $\mathrm{C}-5$ has inverted stereochemistry, whilst the functionality at $\mathrm{C}-7$ in $\mathbf{1}$ is an amide with inverted stereochemistry when compared with sialic acids. Additionally, pseudaminic acid also lacks an oxygen at C-9 when compared with sialic acid. Bearing these differences in mind, and remembering that the structural variation found in naturally occurring pseudaminic acids relates to the nature of the $N$-acyl substituents at C-5 and C-7, we envisaged a strategy commencing from $\mathrm{KDN}$, as shown in retrosynthetic terms in Scheme 1. The key transformation in our approach is introduction of the Nitrogen functionality at both C-5 and C-7 in a single step from the bis-activated derivative 5 . Subsequent reduction of the azides, and deoxygenation at C-9 would then lead us to our target compounds.
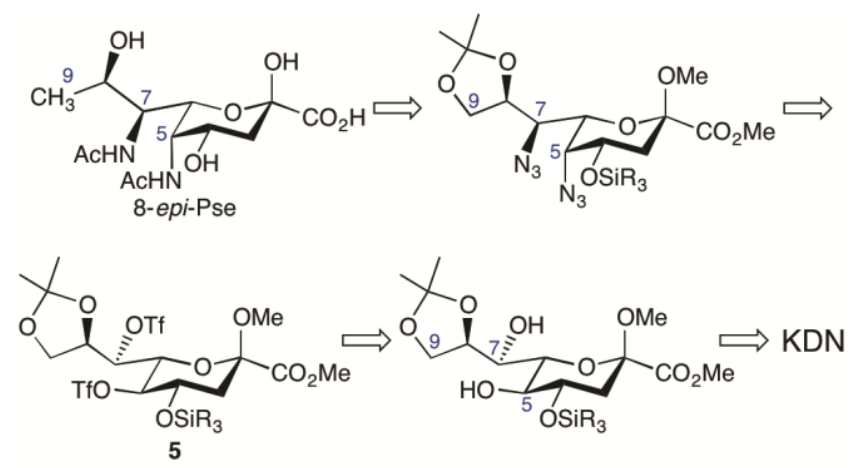

Scheme 1 Our retrosynthetic approach towards pseudaminic acids.

In our initial studies we opted to prepare the $\beta$-methyl glycoside methyl ester of KDN from commercially available $\mathrm{KDN}^{35}$ following the protocol described by Nakamura et al ${ }^{36}$ As described clearly in the Nakamura paper, the proportion of alpha- and beta-methyl glycosides of both furanose and pyranose forms of product obtained under Fischer glycosylation protocol is determined by the reaction conditions, with optimal conditions for formation of predominantly the beta-pyranose product requiring elevated temperature and extended reaction times. ${ }^{36}$ In our hands, no matter how carefully we tried to reproduce the optimal conditions described by Nakamura ${ }^{36}$ we always obtained mixtures of pyranose and furanse products, and their separation required extensive chromatography. Additionally, during the course of our studies we found that KDN was no longer commercially availabile on a preparative scale, and hence we needed to find an alternative strategy. KDN can be routinely prepared using either enzymatic ${ }^{37,38}$ or chemical methods. $^{39}$ We investigated the synthesis of KDN from mannose using the Neu5Ac aldolase catalysed condensation with sodium pyruvate, ${ }^{37}$ but found that in our hands this was not really applicable to large scale synthesis. With respect to chemical synthesis of KDN, we reasoned that any approach to pseudaminic acid starting from KDN itself would always result in alpha- and beta- isomers of both the furanose and pyranose forms, which seemed a little wasteful both in terms of material and time. A potentially more attractive option would be to access the beta-methyl pyranoside of KDN without using KDN itself. In this reagrd, in 1990 Schreiner and Zbiral described a synthesis of KDN from Neu5Ac, ${ }^{40}$ wherein treatment of fully acetylated Neu5Ac methyl ester 6 with nitrosyl acetate efficiently gave the $\mathrm{N}$-nitroso derivative 7, which upon treatment with sodium trifluoroethanolate afforded the 5-diazo derivative 8 (Scheme 2). Exposure of 8 to tetrabutylammonium acetate in acetic acid then gave the desired fully acetylated KDN derivative 9 in $53 \%$ over the two steps. An analogous method reported more recently uses commercially available nitrosyl tetrafluoroborate $\left(\mathrm{NOBF}_{4}\right)$ to achieve the initial $N$-nitroso adduct. ${ }^{41}$

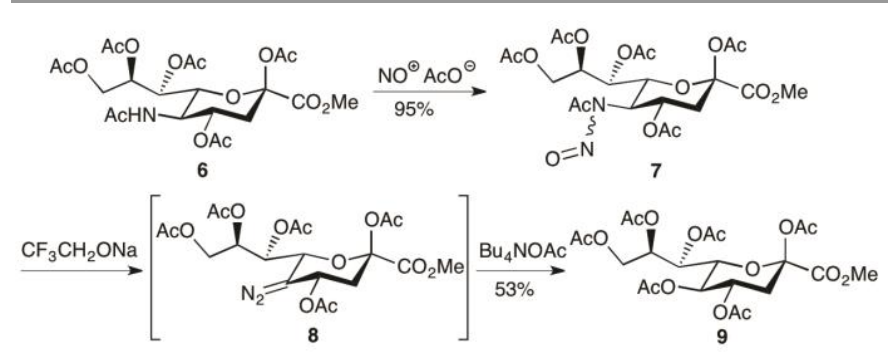

Scheme 2 Schreiner \& Zbiral approach to the synthesis of KDN from Neu5Ac. ${ }^{40}$

In 2002, Glatzhofer et al. reported the direct conversion of $\mathrm{N}$-aromatic secondary amides into $\mathrm{O}$-aromatic esters via $\mathrm{N}$ nitrosamide intermediates using sodium nitrite in a mixture of acetic anhydride and acetic acid. ${ }^{42}$ We wondered if this type of conversion could be applied to aliphatic secondary amides like that found in Neu5Ac. Accordingly, exposure of the methyl ester $\beta$-methyl glycoside $\mathbf{1 0}$ of Neu5Ac to sodium nitrite ( 2 molar eq.) in acetic anhydride and acetic acid under the conditions described by Glatzhofer et al. ${ }^{42}\left(0^{\circ} \mathrm{C}\right.$ for the addition of $\mathrm{NaNO}_{2}$, then 2 hours at $0^{\circ} \mathrm{C}$ and overnight at RT) afforded a modest $(\sim 20 \%)$ yield of the KDN derivative 11 along with several other minor components. ${ }^{43}$ The modest yield of KDN from this attempt was disappointing, but following from the pivotal work by White during the 1950 's ${ }^{44-46}$ we felt that increasing the excess of sodium nitrite and increasing the reaction temperature after the formation of the N-nitroso intermediate may be beneficial. After some experimentation we found that increasing the excess of sodium nitrite (to 20 molar eq.) and raising the temperature of the thermal decomposition to $50^{\circ} \mathrm{C}$ for several hours resulted in obtaining the protected $\mathrm{KDN}$ derivative 11 in $57 \%$ yield from 10 after chromatography (Scheme 3). Deprotection of 
11 then furnished our target $\beta$-methyl glycoside methyl ester of $\mathrm{KDN}(\mathbf{1 2})$.

Having established an efficient route to $\mathbf{1 2}$ from Neu5Ac, we turned our attention to developing a versatile synthesis of pseudaminic acid analogues. Accordingly, treatment of $\mathbf{1 2}$ with 2,2-dimethoxypropane and acetone in the presence of a trace amount of $p$-toluenesulfonic acid afforded the 8,9-Oisopropylidene $\mathbf{1 3}$ in good yield after purification (Scheme 3). Care needed to be taken with this reaction to ensure the formation of the bis-isopropylidene $\mathbf{1 4}$ was kept to a minimum, and this could best be achieved by limiting the reaction time. Selective silylation of the C-4 hydroxyl in the triol $\mathbf{1 3}$ could be achieved in high yield by exposure of $\mathbf{1 3}$ to tert-butyldimethylsilyl chloride in the presence of imidazole and $N, N$-DMF. In this way the 4-O-silyl ether 15 was obtained in $75 \%$ yield $(97 \%$ based on recovered 13$)$. Unequivocal proof that silylation had occurred exclusively at C-4 was obtained by taking a small amount of $\mathbf{1 3}$ and acetylating ( $\mathrm{Ac}_{2} \mathrm{O} /$ pyridine) (Scheme 3$)$. The resulting bisacetate $\mathbf{1 6}$ showed characteristic changes in the chemical shift of H-5 (from $\delta 3.60$ in $\mathbf{1 5}$ to $\delta 4.89$ in 16) and H-7 (from $\delta$ 3.89 in $\mathbf{1 5}$ to $\delta 5.24$ in 16) consistent with the change from hydroxyl to acetate, whilst the chemical shift of H-4 was essentially unchanged.

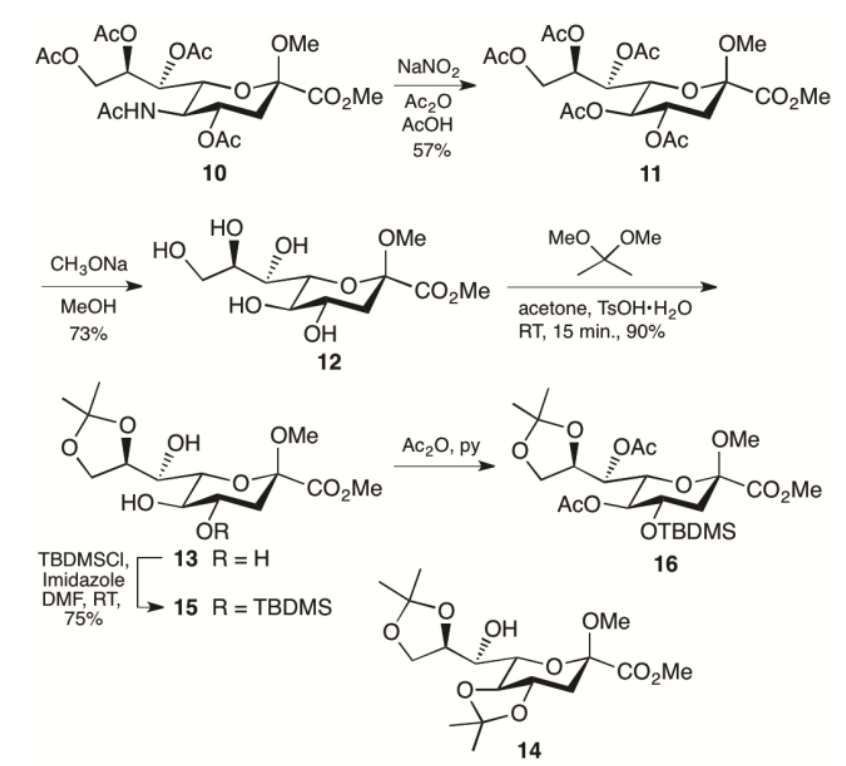

Scheme 3 Synthesis of the key 5,7-diol intermediate 15.

With the key 5,7-diol $\mathbf{1 5}$ in hand, our next target was to introduce the requisite nitrogen functionalities at C-5 and C-7. Accordingly, exposure of $\mathbf{1 5}$ to triflic anhydride (2.5 molar equivalents) gave the bis-triflate $\mathbf{1 7}$ which, without purification was exposed to an excess of sodium azide in $N, N$ DMF at $0^{\circ} \mathrm{C}$ over 24 hours to give the bis-azide 18 in $85 \%$ yield after purification (Scheme 4). Spectroscopic analysis of 18 confirmed introduction of two azide functionalities $(\mathrm{m} / \mathrm{z}$ 523 for $[\mathrm{M}+\mathrm{Na}]$ and a strong peak at $2110 \mathrm{~cm}^{-1}$ in the IR spectrum). The ${ }^{1} \mathrm{H}$ nmr spectrum of $\mathbf{1 8}$ clearly shows the effect of inverting the stereochemistry at both $\mathrm{C}-5$ and $\mathrm{C}-7$. In sialic acid derivatives, typical $J_{\mathrm{H}, \mathrm{H}}$ couplings for the protons involved are $J_{4,5}=9.0 \mathrm{~Hz}, J_{5,6}=9.6 \mathrm{~Hz}, J_{6,7}=1.2 \mathrm{~Hz}$, and $J_{7,8}=8.7 \mathrm{~Hz}$. In the ${ }^{1} \mathrm{H} \mathrm{nmr}$ spectrum of the bis-azide $\mathbf{1 8}$, we observe $J_{4,5}=4.8 \mathrm{~Hz}, J_{5,6}=1.5 \mathrm{~Hz}, J_{6,7}=9.9 \mathrm{~Hz}$, and $J_{7,8}=$ $4.5 \mathrm{~Hz}$. These changes in coupling, especially around the ring protons, are clearly consistent with inversion of stereochemistry at both C-5 and C-7.

Delighted with having introduced the requisite nitrogen functionalities at both $\mathrm{C}-5$ and C-7 in a single transformation, we opted to explore the reduction of the azide groups and subsequent bis-acylation. Exposure of $\mathbf{1 8}$ to palladium on carbon under an atmosphere of hydrogen, followed by filtration to remove the palladium and then acetylation $\left(\mathrm{Ac}_{2} \mathrm{O}\right.$, pyridine), smoothly afforded a single compound in $88 \%$ yield (Scheme 4). Interestingly, the ${ }^{1} \mathrm{H}$ nmr spectrum of this product showed that it was not the expected bis-acetamide, but rather a compound that contained only a single acetamide group (one 3 proton singlet at $\delta 2.03$ ), but had two amide $\mathrm{NH}$ protons (doublets at $\delta 5.77$ and 6.55) and also lacked the methyl ester protons. Careful analysis of all the spectroscopic data, including a parent ion at $m / z 481\left(\mathrm{C}_{21} \mathrm{H}_{38} \mathrm{~N}_{2} \mathrm{O}_{7} \mathrm{Si}+\mathrm{Na}\right)$ in the mass spectrum and changes to couplings observed around the sugar ring in the ${ }^{1} \mathrm{H}$ NMR spectrum indicated that this unexpected product was in fact the 1,5-lactam 19. Most notably in the ${ }^{1} \mathrm{H}$ NMR spectrum of $\mathbf{1 9}$, the coupling between $\mathrm{H}-3 \mathrm{ax}$ and $\mathrm{H}-4$ was $1.8 \mathrm{~Hz}$ (compared to $J_{3 \mathrm{ax}, 4}=9.3 \mathrm{~Hz}$ in 18) and the coupling between $\mathrm{H}-5$ and $\mathrm{H}-6$ was $2.7 \mathrm{~Hz}$ (compared

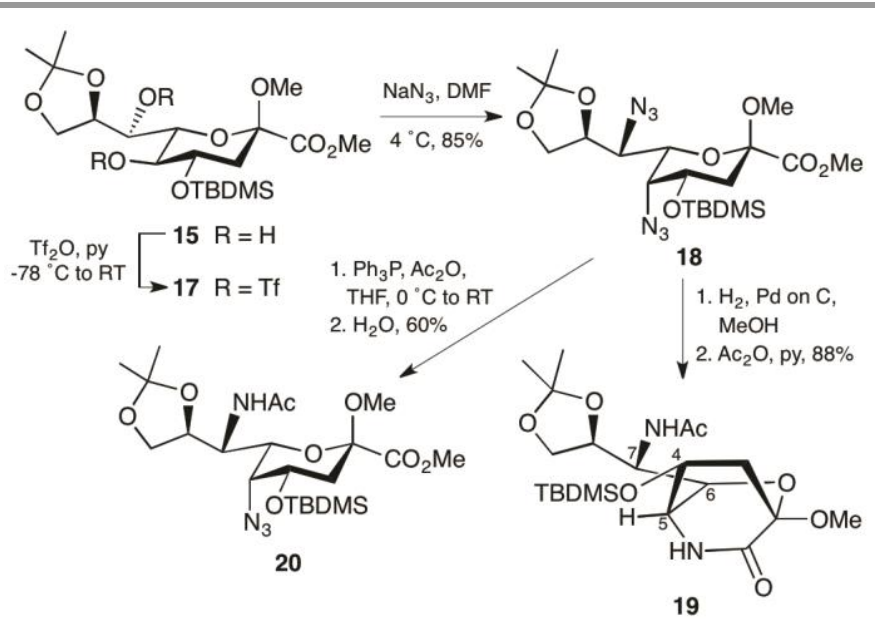

Scheme 4 Synthesis of key bis-azide 18, and attempted reduction of azides.

to $J_{5,6} \sim 9.5 \mathrm{~Hz}$ in sialic acids with a ${ }^{2} \mathrm{C}_{5}$ chair conformation). Both of these changes in magnitude of coupling between the ring protons strongly suggested a change to the pyranose ring conformation to a boat (or strained boat) in the 1,5-lactam 19 . Unequivocal proof that we had indeed formed the 1,5-lactam derivative 19 came from two-dimensional NMR spectroscopy which showed appropriate long-range $\mathrm{C}-\mathrm{H}$ correlations to support the 1,5-lactam structure 19.

Precisely when the 1,5-lactam 19 forms is not yet clear to us, but presumably involves nucleophilic attack of the newly 
generated C-5 amine onto the ester. Significantly in the context of synthesising pseudaminic acid analogues, the efficient formation of the 1,5-lactam ring could conceivably be used to allow the selective acylation of each of the two amines present. This is important in the context of pseudaminic acid analogues, since the naturally occuring pseudaminic acids often have different acyl groups attached to the nitrogens at $\mathrm{C}-5$ and $\mathrm{C}-7 .{ }^{9,10}$ Although we are yet to pursue this option with compound $\mathbf{1 9}$ as the substrate, subsequent experiments on the bis-azide 18 (vide infra) provided clear evidence that the two nitrogen functionalities in $\mathbf{1 8}$ can indeed be differentiated.

Returning to the bis-azide $\mathbf{1 8}$, we wondered if we could prevent the 1,5-lactam formation by trapping the newly generated amine in situ with an acylating reagent. We felt this could perhaps be most effectively achieved using a Staudinger reduction on $\mathbf{1 8}$ in the presence of acetyl chloride or acetic anhydride. Accordingly, exposure of $\mathbf{1 8}$ to triphenylphosphine and then acetic anhyride gave a complex reaction mixture after aqueous hydrolysis of the intermediate iminophosphorane. Interestingly, whilst the crude reaction mixture contained multiple products, we isolated a single major component in $60 \%$ yield that was not the expected bisacetamide. Careful analysis of the spectroscopic data indicated that this compound was the 7-acetamide-5-azido derivative 20 (Scheme 4). This was evident from the ${ }^{1} \mathrm{H}$ NMR spectrum of $\mathbf{2 0}$ which showed only one NH resonance at $\delta 5.88$ that coupled to the $\mathrm{H}-7$ proton $(\delta$ 4.34). Additionally, the I.R. spectrum of $\mathbf{2 0}$ showed a clear azide stretch $\left(2105 \mathrm{~cm}^{-1}\right)$, and the mass spectrum showed the expected $[\mathrm{M}+\mathrm{Na}]$ peak $(\mathrm{m} / \mathrm{z} 539)$ for $\mathbf{2 0}$. Although the yield of $\mathbf{2 0}$ from $\mathbf{1 8}$ has yet to be optimised, the outcome from this Staudinger reduction clearly shows that the two azide groups in 18 can be chemically distinguished, thus allowing ready access to a range of pseudaminic acid analogues.

Returning to our desire to reduce both azide groups in $\mathbf{1 8}$ in a single reaction, we opted to undertake hydrogenation of $\mathbf{1 8}$ $\left(\mathrm{Pd}(\mathrm{OH})_{2}\right.$ on $\mathrm{C}$ in $\left.\mathrm{MeOH}\right)$ with the addition of a trace amount of $p$-tolenesulfonic acid to the hydrogenation reaction. This proved effective, with the desired bis-acetamide 21 being isolated in $81 \%$ yield after acetylation $\left(\mathrm{Ac}_{2} \mathrm{O}\right.$ /pyridine) of the crude hydrogenation product (Scheme 5). The presence of the two acetamide groups in $\mathbf{2 1}$ was evident from examination of the ${ }^{1} \mathrm{H} \mathrm{nmr}$ spectrum which showed clear peaks for the two acetamide methyl groups ( $\delta 1.92$ and 1.95$)$, as well as the two $\mathrm{NH}$ protons at $\delta 5.55$ and $\delta 5.46$, due to the $\mathrm{C}-5$ and $\mathrm{C}-7$ acetamides, respectively. Removal of the silyl ether and 8,9isopropylidene group in $\mathbf{2 1}$ was accomplished in a single step using aqueous trifluoroacetic acid in a THF/water mixture, producing the triol 22 in $85 \%$ yield. Iodination of $\mathbf{2 2}\left(\mathrm{I}_{2}\right.$, $\mathrm{Ph}_{3} \mathrm{P}$, imidazole) gave the 9 -iodo derivative 23 in $71 \%$ yield.

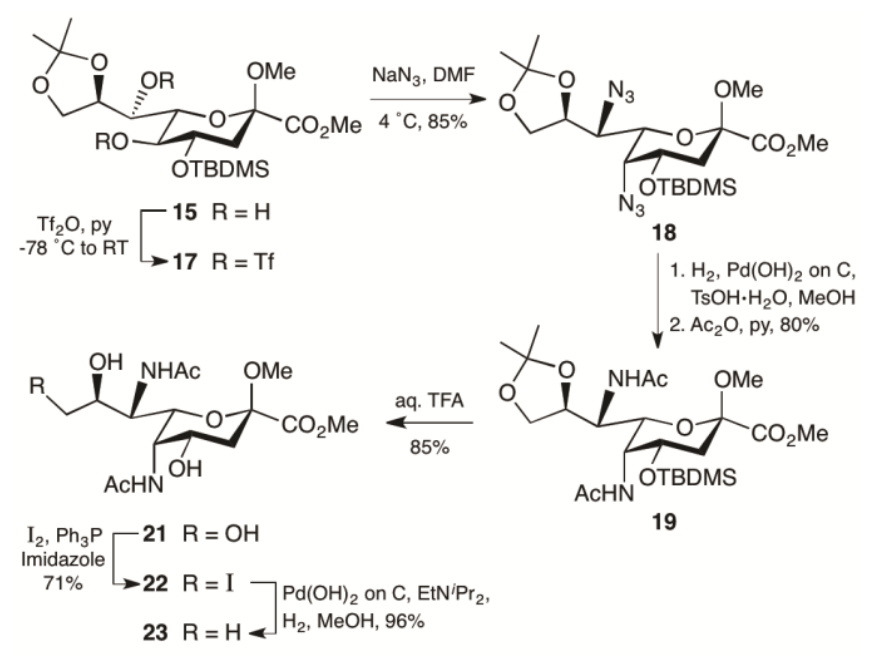

Scheme 5 Synthesis of 8-epi-pseudaminic acid from the bis-azide $\mathbf{1 8}$

The modest yield is most probably due to difficulties we encountered during workup, most notably that the product is partially water soluble which made separation from the triphenylphosphine oxide and subsequent purification complicated. Nonetheless, spectroscopic analysis of $\mathbf{2 3}$ clearly showed the presence of an iodine attached to C-9, since the chemical shift of C-9 was $\delta 9.4$ in 23 compared with $\delta 64.8$ in 22, whilst a $\mathrm{m} / \mathrm{z}$ at 511 is consistent with the expected $[\mathrm{M}+\mathrm{Na}]$ peak. Reduction of the 9-iodo group $\left(\mathrm{Pd}(\mathrm{OH})_{2}, \mathrm{EtN}^{i} \mathrm{Pr}_{2}, \mathrm{H}_{2}\right)$ smoothly afforded the desired 8-epiPse 24 in 96\% yield (Scheme 4). Successful introduction of the target 9-deoxy group is clearly observed in the ${ }^{1} \mathrm{H} \mathrm{nmr}$ spectrum of 24 which shows a 3 proton doublet at $\delta 1.06$ for the C-9 methyl group, along with the associated change in the multiplicity of the signal for $\mathrm{H}-8$.

\section{Conclusions}

In summary, our synthesis of the $\beta$-methyl glycoside methyl ester of 8-epi-pseudamininc acid (24) in 8 steps and an overall $26 \%$ yield from 12 represents a significant achievement in the field of nonulosonic acid chemistry. One key feature of our approach is the development of a route to protected KDN derivatives directly from Neu5Ac, which is a particularly important addition to nonulosonic acid chemistry, given that KDN is very expensive and not commercially available on a preparative scale. Our approach towards pseudaminic acid analogues from $\mathrm{KDN}$ is notable in that it achieves introduction of the requisite bis-nitrogen functionalities at C-5 and C-7 via the bis-azide $\mathbf{1 8}$. The significance of the bis-azide $\mathbf{1 8}$ as a key synthetic intermediate is shown by the ready formation of the 1,5lactam 19, and also by the use of a Staudinger reaction to selectively generate the 7-acetamido-5-azido derivative $\mathbf{2 0}$. The ability to chemically distinguish between the two azide groups in $\mathbf{1 8}$ is important, since most naturally occurring pseudaminic acids have different amides at C-5 and C-7., ${ }^{9,10}$ Therefore, with some further refinement, the Staudinger 
reaction on $\mathbf{1 8}$ could be exploited in order to provide access to compounds closely related to the naturally occurring pseudaminic acids that have different acetamides at C-5 and C-7. We are currenrtly investigating the use of compounds like $\mathbf{1 8}$ and $\mathbf{2 0}$ as precursors for selectively functionalised analogues of Pse.

\section{Experimental}

\section{General}

All solvents were distilled prior to use and reagents were purchased from Sigma unless otherwise stated. NMR spectra were recorded using a Bruker $300 \mathrm{MHz}$ spectrometer operating at $300 \mathrm{MHz}$ and $75.5 \mathrm{MHz}$ for ${ }^{1} \mathrm{H}$ and ${ }^{13} \mathrm{C}$ NMR spectra, respectively, unless indicated otherwise. COSY and HSQC two-dimensional spectra were used to aid with assignments. Mass spectroscopy was performed using Bruker Esquire 3000 Ion trap electrospray ionisation Mass Spectrometer. Column chromatography ("flash") was carried out using Merck Kieselgel 60 silica gel, and reactions were monitored using Merck Kieselgel $60 \mathrm{~F}_{254}$ aluminium backed T.L.C. plates. Visualisation of T.L.C.'s involved dipping plates into a $5 \% \mathrm{H}_{2} \mathrm{SO}_{4}$ in EtOH solution, and then heating the plate at $\sim 150^{\circ} \mathrm{C}$.

The synthesis of KDN1, $\beta 2 \mathrm{Me}_{2}(\mathbf{1 2})$ from KDN (purchased from Codexis in 2009) ${ }^{35}$ was carried out following the procedure described by Nakamura et al. ${ }^{36}$ The synthesis of per-acetylated Neu5Ac1, $\beta 2 \mathrm{Me}_{2}$ (10) from Neu5Ac (purchased from Carbosynth Ltd, UK) was carried out following the procedure described by Kuhn et al., ${ }^{47}$ and subsequent acetylation $\left(\mathrm{Ac}_{2} \mathrm{O}\right.$ - pyridine). All spectroscopic data for these compounds was in agreement with published data.

\section{Conversion of Neu5Ac into KDN}

Methyl (methyl 4,5,7,8,9-penta- $O$-acetyl-3-deoxy-Dglycero- $\beta$-D-galacto-non-2-ulopyranosid)onate (11). To a solution of 11 (2.33 g, $4.60 \mathrm{mmol})$ in $\mathrm{Ac}_{2} \mathrm{O} / \mathrm{AcOH}(2: 1,40 \mathrm{~mL})$ at $0{ }^{\circ} \mathrm{C}$, was added $\mathrm{NaNO}_{2}(6.34 \mathrm{~g}, 91.9 \mathrm{mmol})$. The vessel was loosely stoppered to allow a yellow gas to be released. After stirring at $0{ }^{\circ} \mathrm{C}$ for $1 \mathrm{~h}$, and a further $6 \mathrm{~h}$ at $50{ }^{\circ} \mathrm{C}$, the mixture was poured into $100 \mathrm{~mL}$ ice/water, stirred for a further 10 minutes, and extracted into EtOAc $(3 \times 150 \mathrm{~mL})$. The combined organic phase was washed with saturated aqueous $\mathrm{NaHCO}_{3}(3 \times 50 \mathrm{~mL})$ before being dried $\left(\mathrm{Na}_{2} \mathrm{SO}_{4}\right)$, and concentrated in vacuo. The desired product (1.33 g, 57\%) was obtained using column chromatography (EtOAc/hexanes, 1:1, $\left.\mathrm{R}_{\mathrm{f}}=0.30\right) .{ }^{1} \mathrm{H} \mathrm{NMR}\left(\mathrm{CDCl}_{3}\right) \delta: 1.84\left(\mathrm{dd}, 1 \mathrm{H}, J_{3 \mathrm{ax}, 3 \mathrm{eq}}=12.9\right.$ $\left.\mathrm{Hz}, J_{3 \mathrm{ax}, 4}=11.4 \mathrm{~Hz}, \mathrm{H}-3_{\mathrm{ax}}\right), 1.98,2.01,2.02,2.07,2.11(\mathrm{~s}, 3 \mathrm{H}$, $\left.\mathrm{OCOCH}_{3}\right), 2.51\left(\mathrm{dd}, 1 \mathrm{H}, J_{3 \mathrm{eq}, 3 \mathrm{ax}}=12.9 \mathrm{~Hz}, J_{3 \mathrm{eq}, 4}=5.4 \mathrm{~Hz}, \mathrm{H}-\right.$ $\left.3_{\text {eq }}\right), 3.25\left(\mathrm{~s}, 3 \mathrm{H}, \mathrm{OCH}_{3}\right), 3.80\left(\mathrm{~s}, 3 \mathrm{H}, \mathrm{CO}_{2} \mathrm{CH}_{3}\right), 4.05$ (dd, $1 \mathrm{H}$, $\left.J_{6,5}=9.9 \mathrm{~Hz}, J_{6,7}=2.1 \mathrm{~Hz}, \mathrm{H}-6\right), 4.14\left(\mathrm{dd}, 1 \mathrm{H}, J_{9^{\prime}, 9}=12.6 \mathrm{~Hz}\right.$, $\left.J_{9^{\prime}, 8}=6.6 \mathrm{~Hz}, \mathrm{H}^{\prime} 9^{\prime}\right), 4.70\left(\mathrm{dd}, 1 \mathrm{H}, J_{9,9}=12.6 \mathrm{~Hz}, J_{9,8} 2.4 \mathrm{~Hz}\right.$, H-9), 4.89 (dd, $\left.1 \mathrm{H}, J_{5,6}=9.9 \mathrm{~Hz}, J_{5,4}=9.9 \mathrm{~Hz}, \mathrm{H}-5\right), 5.26-5.35$ $(\mathrm{m}, 2 \mathrm{H}, \mathrm{H}-4, \mathrm{H}-8), 5.40\left(\mathrm{dd}, 1 \mathrm{H}, J_{7,8}=5.4 \mathrm{~Hz}, J_{7,6}=2.1 \mathrm{~Hz}\right.$,
H-7). $\quad{ }^{13} \mathrm{C} \mathrm{NMR}\left(\mathrm{CDCl}_{3}\right) \delta: 20.6,20.7,20.8,20.9,21.0$ $\left(\mathrm{COCH}_{3}\right), 36.8(\mathrm{C}-3), 51.3\left(\mathrm{OCH}_{3}\right), 52.7\left(\mathrm{CO}_{2} \mathrm{CH}_{3}\right), 62.0(\mathrm{C}-9)$, 67.4 (C-7), 67.7 (C-5), 69.0 (C-4), 69.9 (C-6), 70.7 (C-8), 98.7 $(\mathrm{C}-2), \quad 167.1 \quad(\mathrm{C}-1), \quad 169.8, \quad 169.9, \quad 170.1, \quad 170.2, \quad 170.6$ $\left(\mathrm{OCOCH}_{3}\right)$. ES-MS: $m / z=529[\mathrm{M}+\mathrm{Na}]^{+}$.

\section{Conversion of KDN into 8-epi-Pse}

Methyl (methyl 3-deoxy-8,9-O-isopropylidene-D-glycero$\boldsymbol{\beta}$-D-galacto-non-2-ulopyranosid)onate (13). 2,2-Dimethoxypropane $(0.33 \mathrm{~mL}, 2.68 \mathrm{mmol})$ and $p$-toluenesulphonic acid monohydrate $(73 \mathrm{mg}, 0.38 \mathrm{mmol})$ were added to a stirred solution of $6(570 \mathrm{mg}, 1.92 \mathrm{mmol})$ in dry acetone $(10 \mathrm{~mL})$ under $\mathrm{N}_{2(\mathrm{~g})}$ at room temperature. The resulting solution was kept at room temperature for 30 minutes before being neutralised with triethylamine and concentrated under reduced pressure. The resulting pale yellow residue was purified using column chromatography (EtOAc, $\mathrm{R}_{\mathrm{f}}=0.25$ ) yielding 13 $(577 \mathrm{mg}, 90 \%)$ as a white solid. Our spectroscopic data is consistent with that reported. ${ }^{48}{ }^{1} \mathrm{H}$ NMR $\left(\mathrm{CDCl}_{3}\right) \delta: 1.31,1.39$ $\left(\mathrm{s}, 3 \mathrm{H}, \mathrm{C}\left(\mathrm{CH}_{3}\right)_{2}\right), 1.58\left(\mathrm{dd}, 1 \mathrm{H}, J_{3 \mathrm{ax}, 3 \mathrm{eq}}=12.9 \mathrm{~Hz}, J_{3 \mathrm{ax}, 4}=12.0\right.$ $\left.\mathrm{Hz}, \mathrm{H}-3_{\mathrm{ax}}\right), 2.29\left(\mathrm{dd}, 1 \mathrm{H}, J_{3 \mathrm{eq}, 3 \mathrm{ax}}=12.9 \mathrm{~Hz}, J_{3 \mathrm{eq}, 4}=5.1 \mathrm{~Hz}, \mathrm{H}-\right.$ $3_{\text {eq }}$ ), $3.42\left(\mathrm{~s}, 3 \mathrm{H}, \mathrm{OCH}_{3}\right), 3.49\left(\mathrm{dd}, 1 \mathrm{H}, J_{5,6}=9.6 \mathrm{~Hz}, J_{5,4}=9.0\right.$ $\mathrm{Hz}, \mathrm{H}-5), 3.67$ (dd, $\left.1 \mathrm{H}, J_{6,5}=9.6 \mathrm{~Hz}, J_{6,7}=1.2 \mathrm{~Hz}, \mathrm{H}-6\right), 3.82$ $\left(\mathrm{dd}, 1 \mathrm{H}, J_{7,8}=8.7 \mathrm{~Hz}, J_{7,6}=1.2 \mathrm{~Hz}, \mathrm{H}-7\right), 3.84(\mathrm{~s}, 3 \mathrm{H}$, $\left.\mathrm{CO}_{2} \mathrm{CH}_{3}\right), 3.89\left(\mathrm{ddd}, 1 \mathrm{H}, J_{4,3 \mathrm{ax}}=12.0 \mathrm{~Hz}, J_{4,5}=9.0 \mathrm{~Hz}, J_{4,3 \mathrm{eq}}=\right.$ $5.1 \mathrm{~Hz}, \mathrm{H}-4), 3.99$ (dd, $1 \mathrm{H}, J_{9,9}=8.4 \mathrm{~Hz}, J_{9,8} 5.7 \mathrm{~Hz}, \mathrm{H}-9$ ), $4.14\left(\mathrm{dd}, 1 \mathrm{H}, J_{9,, 9}=8.4 \mathrm{~Hz}, J_{9^{\prime}, 8} 5.7 \mathrm{~Hz}, \mathrm{H}-9\right), 4.24(\mathrm{dd}, 1 \mathrm{H}$, $\left.J_{8,7}=8.4 \mathrm{~Hz}, J_{8,9} 5.7 \mathrm{~Hz}, \mathrm{H}-8\right) .{ }^{13} \mathrm{C} \mathrm{NMR}\left(\mathrm{CDCl}_{3}\right) \delta: 25.7,27.2$ $\left(\mathrm{C}\left(\mathrm{CH}_{3}\right)_{2}\right), 40.9(\mathrm{C}-3), 51.5\left(\mathrm{OCH}_{3}\right), 53.4\left(\mathrm{CO}_{2} \mathrm{CH}_{3}\right), 68.8(\mathrm{C}-$ 9), 70.1 (C-4), 70.9 (C-7), 71.2 (C-6), 73.7 (C-5), 76.0 (C-8), $100.5(\mathrm{C}-2), 110.4\left(C\left(\mathrm{CH}_{3}\right)_{2}\right), 171.6\left(\mathrm{CO}_{2} \mathrm{CH}_{3}\right)$. ES-MS: $m / z=$ $359.5[\mathrm{M}+\mathrm{Na}]^{+}$.

Methyl (methyl 4-O-(tert-butyldimethylsilyl)-3-deoxy8,9-O-isopropylidene- D-glycero- $\beta$-D-galacto-non-2ulopyranosid)onate (15). Imidazole (328 $\mathrm{mg}, 4.82 \mathrm{mmol}$ ) and TBDMSCl (363mg, $2.41 \mathrm{mmol}$ ) were added to a stirred solution of 13 (577 mg, $1.72 \mathrm{mmol}$ ) in anhydrous DMF (10 $\mathrm{mL}$ ) under $\mathrm{N}_{2(\mathrm{~g})}$ at room temperature. The resulting reaction mixture was stirred for 16 hours at room temperature before being concentrated under reduced pressure and purified directly using column chromatography $\left(\right.$ EtOAc, $\left.\mathrm{R}_{\mathrm{f}}=0.8\right)$ yielding $\mathbf{1 5}$ (605mg, 75\%, 97\% based on recovered 13) as a white solid. Our spectroscopic data is consistent with that reported. ${ }^{43}{ }^{1} \mathrm{H}$ NMR $\left(\mathrm{CDCl}_{3}\right) \delta: 0.11\left(\mathrm{~d}, 6 \mathrm{H}, \mathrm{Si}\left(\mathrm{CH}_{3}\right)_{2}\right), 0.89$ (s, $9 \mathrm{H}$, $\left.\mathrm{SiC}\left(\mathrm{CH}_{3}\right)_{3}\right), 1.31,1.41\left(\mathrm{~s}, 3 \mathrm{H}, \mathrm{C}\left(\mathrm{CH}_{3}\right)_{2}\right), 1.66\left(\mathrm{dd}, 1 \mathrm{H}, J_{3 \mathrm{ax}, 3 \mathrm{eq}}\right.$ $\left.=12.9 \mathrm{~Hz}, J_{3 \mathrm{ax}, 4}=12.0 \mathrm{~Hz}, \mathrm{H}-3_{\mathrm{ax}}\right), 2.30\left(\mathrm{dd}, 1 \mathrm{H}, J_{3 \mathrm{eq}, 3 \mathrm{ax}}=12.9\right.$ $\left.\mathrm{Hz}, J_{3 \mathrm{eq}, 4}=5.4 \mathrm{~Hz}, \mathrm{H}-3_{\mathrm{eq}}\right), 2.70\left(\mathrm{~d}, 1 \mathrm{H}, J_{\mathrm{OH}, 5}=3.3 \mathrm{~Hz}, \mathrm{OH}\right)$, $3.25\left(\mathrm{~s}, 3 \mathrm{H}, \mathrm{OCH}_{3}\right), 3.60\left(\mathrm{ddd}, 1 \mathrm{H}, J_{5,6}=9.6 \mathrm{~Hz}, J_{5,4}=9.0 \mathrm{~Hz}\right.$, $\left.J_{5, \mathrm{OH}}=3.3 \mathrm{~Hz} \mathrm{H}-5\right), 3.76\left(\mathrm{dd}, 1 \mathrm{H}, J_{6,5}=9.6 \mathrm{~Hz}, J_{6,7}=1.2 \mathrm{~Hz}\right.$, $\mathrm{H}-6), 3.80\left(\mathrm{~s}, 3 \mathrm{H}, \mathrm{CO}_{2} \mathrm{CH}_{3}\right), 3.89\left(\mathrm{dd}, 1 \mathrm{H}, J_{7,8}=8.7 \mathrm{~Hz}, J_{7,6}=\right.$ 1.2 Hz, H-7), 3.97-4.09 (m, 2 H, H-4, H-9'), 4.11-4.21 (m, 2 H, $\mathrm{H}-8, \quad \mathrm{H}-9) . \quad{ }^{13} \mathrm{C} \quad \mathrm{NMR} \quad\left(\mathrm{CDCl}_{3}\right) \quad \delta:-4.5 \quad \mathrm{Si}\left(\mathrm{CH}_{3}\right) 2, \quad 17.9$ $\left(\mathrm{SiC}\left(\mathrm{CH}_{3}\right)_{3}\right), 25.4\left(\mathrm{C}\left(\mathrm{CH}_{3}\right)_{2}\right), 25.6\left(\mathrm{Si}\left(\mathrm{CH}_{3}\right)_{2}\right), 26.8\left(\mathrm{C}_{\left.\left(\mathrm{CH}_{3}\right)_{2}\right)}\right.$, 40.4 (C-3), $50.9\left(\mathrm{OCH}_{3}\right), 52.7\left(\mathrm{CO}_{2} \mathrm{CH}_{3}\right), 67.7$ (C-9), $70.2(\mathrm{C}-$ 7), 70.3 (C-4), 70.6 (C-5), 71.8 (C-6), 74.8 (C-8), 99.2 (C-2), 


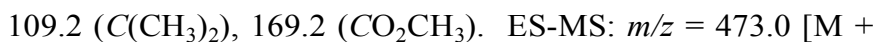
$\mathrm{Na}]^{+}$.

Methyl (methyl 5,7-di- $O$-acetyl-4- $O$-(tert-butyldimethylsilyl)-3-deoxy-8,9- $O$-isopropylidene-D-glycero- $\beta$-D-galacto-

non-2-ulopyranosid)onate (16). A small portion $(\sim 100 \mathrm{mg})$ of 15 was acetylated $\left(\mathrm{Ac}_{2} \mathrm{O} /\right.$ pyridine $)$ overnight. The residue was purified using column chromatography (EtOAc/hexanes, 1:4, $\mathrm{R}_{\mathrm{f}}$ $=0.35)$ yielding $\mathbf{1 6}$ as an amorphous mass. ${ }^{1} \mathrm{H}$ NMR $\left(\mathrm{CDCl}_{3}\right)$

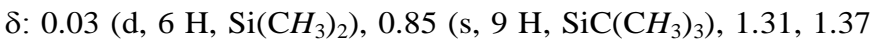
$\left(\mathrm{s}, 3 \mathrm{H}, \mathrm{C}\left(\mathrm{CH}_{3}\right)_{2}\right), 1.80\left(\mathrm{dd}, 1 \mathrm{H}, J_{3 \mathrm{ax}, 3 \mathrm{eq}}=12.9 \mathrm{~Hz}, J_{3 \mathrm{ax}, 4}=11.1\right.$ $\left.\mathrm{Hz}, \mathrm{H}-3_{\mathrm{ax}}\right), 2.02,2.10\left(2 \mathrm{~s}, 3 \mathrm{H}, \mathrm{COCH}_{3}\right), 2.20\left(\mathrm{dd}, 1 \mathrm{H}, J_{3 \mathrm{eq}, 3 \mathrm{ax}}\right.$ $\left.=12.9 \mathrm{~Hz}, J_{3 \mathrm{eq}, 4}=5.4 \mathrm{~Hz}, \mathrm{H}-3_{\mathrm{eq}}\right), 3.26\left(\mathrm{~s}, 3 \mathrm{H}, \mathrm{OCH}_{3}\right), 3.81(\mathrm{~s}$, $3 \mathrm{H}, \mathrm{CO}_{2} \mathrm{CH}_{3}$ ), 3.89-3.96 (m, $\left.2 \mathrm{H}, \mathrm{H}-6, \mathrm{H}-9\right), 4.01-4.09$ (m, 2 $\mathrm{H}, \mathrm{H}-4, \mathrm{H}-9^{\prime}$ ), 4.36 (ddd, $1 \mathrm{H}, J_{8,7}=8.7 \mathrm{~Hz}, J_{8,9}=J_{8,9}=5.7 \mathrm{~Hz}$, $\mathrm{H}-8) .4 .89$ (dd, $\left.1 \mathrm{H}, J_{5,6}=J_{5,4}=9.6 \mathrm{~Hz}, \mathrm{H}-5\right), 5.24\left(\mathrm{dd}, 1 \mathrm{H}, J_{7,8}\right.$ $\left.=6.6 \mathrm{~Hz}, J_{7,6}=2.1 \mathrm{~Hz}, \mathrm{H}-7\right)$.

Methyl (methyl 5,7-di-azido-4-O-(tert-butyldimethylsilyl)-3,5,7-tri-deoxy-8,9-O-isopropylidene-L-glycero- $\beta$-L-

manno-non-2-ulopyranosid)onate (18). To a stirred solution of $15(605 \mathrm{mg}, 1.27 \mathrm{mmol})$ in anhydrous $\mathrm{CH}_{2} \mathrm{Cl}_{2}(10 \mathrm{~mL})$ at $78^{\circ} \mathrm{C}$ under $\mathrm{N}_{2}$ was added pyridine $(0.62 \mathrm{~mL}, 7.62 \mathrm{mmol})$ and trifluorormethanesulphonic anhydride $(0.64 \mathrm{~mL}, 3.81 \mathrm{mmol})$. The resulting reaction mixture was stirred at $-78^{\circ} \mathrm{C}$ for 10 minutes, and then kept at $0^{\circ} \mathrm{C}$ for 1 hour, before being allowed to warm to room temperature for 5 hours. The reaction mixture was diluted with $\mathrm{CH}_{2} \mathrm{Cl}_{2}(20 \mathrm{~mL})$, washed with ice-cold dilute aqueous $\mathrm{HCl}(1 \mathrm{M}, 20 \mathrm{~mL})$ and water $(20 \mathrm{~mL})$, the organic phase was dried $\left(\mathrm{Na}_{2} \mathrm{SO}_{4}\right)$ and concentrated under reduced pressure before being purified using column chromatography $\left(\mathrm{Hex} /\right.$ EtOAc $\left.(5: 1), \mathrm{R}_{\mathrm{f}}=0.4\right)$ yielding the bis-triflate $17(785$ $\mathrm{mg}, 86 \%)$ as a yellow oil. Without characterisation the bistriflate 17 was treated with sodium azide as follows:

Sodium azide $(825 \mathrm{mg}, 12.7 \mathrm{mmol})$ was added to a stirred solution of the bis-triflate $\mathbf{1 7}(785 \mathrm{mg}, 1.1 \mathrm{mmol})$ in anhydrous DMF $(20 \mathrm{~mL})$ under $\operatorname{Ar}_{(\mathrm{g})}$ at $0^{\circ} \mathrm{C}$. The resulting reaction mixture was stirred at $4^{\circ} \mathrm{C}$ for 24 hours before being concentrated under reduced pressure and chromatographed on silica gel $\left(\mathrm{Hex} /\right.$ EtOAc $\left.(5: 1), \mathrm{R}_{\mathrm{f}}=0.45\right)$ yielding $18(610 \mathrm{mg}$, 98\%) as an opaque solid. ${ }^{1} \mathrm{H}$ NMR $\left(\mathrm{CDCl}_{3}\right) \delta: 0.10(\mathrm{~d}, 6 \mathrm{H}$, $\left.\mathrm{Si}\left(\mathrm{CH}_{3}\right)_{2}\right), 0.89\left(\mathrm{~s}, 9 \mathrm{H}, \mathrm{SiC}\left(\mathrm{CH}_{3}\right)_{3}\right), 1.31,1.45(\mathrm{~s}, 3 \mathrm{H}$, $\left.\mathrm{C}\left(\mathrm{CH}_{3}\right)_{2}\right), 1.99\left(\mathrm{~m}, 2 \mathrm{H}, \mathrm{H}-3_{\mathrm{ax}} / \mathrm{H}-3_{\mathrm{eq}}\right), 3.17\left(\mathrm{~s}, 3 \mathrm{H}, \mathrm{OCH}_{3}\right), 3.57$ $\left(\mathrm{dd}, 1 \mathrm{H}, J_{7,6}=9.9 \mathrm{~Hz}, J_{7,8}=4.5 \mathrm{~Hz}, \mathrm{H}-7\right), 3.68\left(\mathrm{dd}, 1 \mathrm{H}, J_{6,5}=\right.$ $\left.1.5 \mathrm{~Hz}, J_{6,7}=9.9 \mathrm{~Hz}, \mathrm{H}-6\right), 3.78\left(\mathrm{~s}, 3 \mathrm{H}, \mathrm{CO}_{2} \mathrm{CH}_{3}\right), 4.83$ (dd, 1 $\left.\mathrm{H}, J_{5,4}=4.8 \mathrm{~Hz}, J_{5,6}=1.5 \mathrm{~Hz}, \mathrm{H}-5\right), 3.96\left(\mathrm{dd}, 1 \mathrm{H}, J_{9,8}=7.2\right.$ $\left.\mathrm{Hz}, J_{9,9}=8.7 \mathrm{~Hz}, \mathrm{H}^{\prime} 9^{\prime}\right), 4.11\left(\mathrm{dd}, 1 \mathrm{H}, J_{9,8}=6.9 \mathrm{~Hz}, J_{9,9^{\prime}}=8.7\right.$ $\mathrm{Hz}, \mathrm{H}-9), 4.30\left(\mathrm{ddd}, 1 \mathrm{H}, J_{4,3 \mathrm{ax}}=9.3 \mathrm{~Hz}, J_{4,3 \mathrm{eq}}=5.1 \mathrm{~Hz}, J_{4,5}=\right.$ $4.8 \mathrm{~Hz}, \mathrm{H}-4), 4.40$ (ddd, $1 \mathrm{H}, J_{8,7}=4.5, \mathrm{~Hz}, J_{8,9}=6.9 \mathrm{~Hz}, J_{8,9}=$ $7.2 \mathrm{~Hz}, \mathrm{H}-8) .{ }^{13} \mathrm{C}$ NMR $\left.\left(\mathrm{CDCl}_{3}\right) \delta:-4.6 \mathrm{Si}\left(\mathrm{CH}_{3}\right)_{2}\right), 17.9$ $\left(\mathrm{SiC}\left(\mathrm{CH}_{3}\right)_{3}\right), 25.2\left(\mathrm{C}\left(\mathrm{CH}_{3}\right)_{2}\right), 25.5\left(\mathrm{SiC}\left(\mathrm{CH}_{3}\right)_{3}\right), 26.0\left(\mathrm{C}\left(\mathrm{CH}_{3}\right)_{2}\right)$, 35.9 (C-3), $51.1\left(\mathrm{OCH}_{3}\right), 52.7\left(\mathrm{CO}_{2} \mathrm{CH}_{3}\right), 61.3(\mathrm{C}-5), 61.5(\mathrm{C}-$ 7), 66.6 (C-9), 67.9 (C-4), 69.5 (C-6), 75.4 (C-8), 99.4 (C-2),

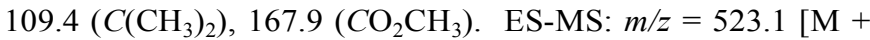
$\mathrm{Na}]^{+}$.

Methyl (methyl 7-acetamido-4-O-(tert-butyldimethylsilyl)-3,5,7-tri-deoxy-1,5-lactam-8,9-O-isopropylidene-Lglycero- $\beta$-L-manno-non-2-ulopyranosid)onate (19). $\quad \mathrm{Pd} / \mathrm{C}$
( $10 \%$ wt.) $(20 \%$ by mass) was added to a solution of the bisazide $18(100 \mathrm{mg}, 0.2 \mathrm{mmol})$ in methanol $(5 \mathrm{~mL})$ under $\operatorname{Argon}_{(\mathrm{g})}$ at room temperature. The resulting reaction mixture was degased and the flask filled with $\mathrm{H}_{2}$ gas, after which the reaction was run at room temperature and pressure for 12 hours under a hydrogen atmosphere. The reaction mixture was filtered through Celite and the filtrate concentrated under reduced pressure. The resulting residue was purified using column chromatography (Hex/EtOAc $\left.(3: 1), \mathrm{R}_{\mathrm{f}}=0.4\right)$ yielding $19(80 \mathrm{mg}, 88 \%)$ as a white solid. This material was crystallised from EtOAc/hexane in order to obtain crystals that were used to obtain preliminary $\mathrm{x}$-ray crystallographic data. ${ }^{49}$ ${ }^{1} \mathrm{H}$ NMR $\left(\mathrm{CDCl}_{3}\right)$ 8: $0.01\left(\mathrm{~d}, 6 \mathrm{H}, \mathrm{Si}\left(\mathrm{CH}_{3}\right)_{2}\right), 0.83$ (s, $9 \mathrm{H}$, $\left.\mathrm{SiC}\left(\mathrm{CH}_{3}\right)_{3}\right), 1.34,1.46\left(\mathrm{~s}, 3 \mathrm{H}, \mathrm{C}\left(\mathrm{CH}_{3}\right)_{2}\right), 1.70\left(\mathrm{dd}, 1 \mathrm{H}, J_{3 \mathrm{ax}, 3 \mathrm{eq}}\right.$ $\left.=14.1 \mathrm{~Hz}, J_{3 \mathrm{ax}, 4}=1.8 \mathrm{~Hz}, \mathrm{H}-3_{\mathrm{ax}}\right), 2.03\left(\mathrm{~s}, 3 \mathrm{H}, \mathrm{NHOCH}_{3}\right), 2.46$ (dd, $\left.1 \mathrm{H}, J_{3 \text { eq, } 3 \text { ax }}=14.1 \mathrm{~Hz}, J_{3 \text { eq, } 4}=8.4 \mathrm{~Hz}, \mathrm{H}-3_{\text {eq }}\right), 3.35$ (br. dd, $\left.1 \mathrm{H}, J_{5, \mathrm{~N} H \mathrm{CO}}=5.7 \mathrm{~Hz}, J_{5,6}=2.7 \mathrm{~Hz}, \mathrm{H}-5\right), 3.55\left(\mathrm{dd}, 1 \mathrm{H}, J_{9,9}=\right.$ $\left.8.4 \mathrm{~Hz}, J_{9,8}=6.3 \mathrm{~Hz}, \mathrm{H}-9^{\prime}\right), 3.59\left(\mathrm{~s}, 3 \mathrm{H}, \mathrm{OCH}_{3}\right), 3.63(\mathrm{dd}, 1 \mathrm{H}$, $\left.J_{6,5}=2.7 \mathrm{~Hz}, J_{6,7}=6.9 \mathrm{~Hz}, \mathrm{H}-6\right), 4.00$ (ddd, $1 \mathrm{H}, J_{7,8}=1.2 \mathrm{~Hz}$, $\left.J_{7,6}=6.9 \mathrm{~Hz}, J_{7,7 \mathrm{NHAc}}=9.0 \mathrm{~Hz}, \mathrm{H}-7\right), 4.07(\mathrm{~m}, 2 \mathrm{H}, \mathrm{H}-9 / \mathrm{H}-4)$, 4.60 (br. dd, $\left.1 \mathrm{H}, J_{8,9}=6.3 \mathrm{~Hz}, J_{8,7}=1.2 \mathrm{~Hz}, \mathrm{H}-8\right), 5.77$ (d, 1 $\left.\mathrm{H}, J_{7 \mathrm{NHAc}, 7}=9.0 \mathrm{~Hz}, 7-\mathrm{N} H \mathrm{Ac}\right), 6.55\left(\mathrm{~d}, 1 \mathrm{H}, J_{5 \mathrm{~N} H \mathrm{CO}, 5}=5.7 \mathrm{~Hz}\right.$, 5-NHCO). $\left.\quad{ }^{13} \mathrm{C} \quad \mathrm{NMR}\left(\mathrm{CDCl}_{3}\right) \quad \delta: \quad-4.7 \quad \mathrm{Si}\left(\mathrm{CH}_{3}\right)_{2}\right), \quad 17.8$ $\left(\mathrm{SiC}\left(\mathrm{CH}_{3}\right)_{3}\right), \quad 23.2 \quad\left(\mathrm{NHCOCH}_{3}\right), \quad 24.1 \quad\left(\mathrm{C}_{\left.\left(\mathrm{CH}_{3}\right)_{2}\right),} \quad 25.6\right.$ $\left(\mathrm{SiC}\left(\mathrm{CH}_{3}\right)_{3}\right), 26.2\left(\mathrm{C}_{\left.\left(\mathrm{CH}_{3}\right)_{2}\right),} 41.9(\mathrm{C}-3), 50.0(\mathrm{C}-7), 52.4\right.$ $\left(\mathrm{OCH}_{3}\right), 54.1(\mathrm{C}-5), 66.0(\mathrm{C}-9), 67.6(\mathrm{C}-4), 72.0(\mathrm{C}-8), 73.0(\mathrm{C}-$ 6), $96.8(\mathrm{C}-2), 109.3\left(\mathrm{C}_{\left.\left(\mathrm{CH}_{3}\right)_{2}\right),} 169.6\left(\mathrm{CO}_{2} \mathrm{CH}_{3}\right), 170.9\right.$ $\left(\mathrm{NHCOCH}_{3} \& \mathrm{NHCO}\right)$. ES-MS: $m / z=481.1[\mathrm{M}+\mathrm{Na}]^{+}$.

Methyl (methyl 7-acetamido-5-azido-4-O-(tert-butyldimethylsilyl)-3,5,7-tri-deoxy-8,9-O-isopropylidene-Dglycero- $\alpha$-L-manno-non-2-ulopyranosid)onate

(20). Molecular sieves $(4 \AA)$ and triphenylphosphine $(231 \mathrm{mg}, 0.88$ $\mathrm{mmol})$ were added to a solution of the bis-azide $18(110 \mathrm{mg}$, $0.22 \mathrm{mmol})$ in THF $(10 \mathrm{~mL})$ under $\operatorname{Argon}_{(\mathrm{g})}$ at $0{ }^{\circ} \mathrm{C}$. The reaction mixture was stirred at $0{ }^{\circ} \mathrm{C}$ for 30 minutes before the addition of acetic anhydride $(208 \mu \mathrm{L}, 2.2 \mathrm{mmol})$ and then stirrd for a further 10 minutes at $0{ }^{\circ} \mathrm{C}$ then 5.5 hours at room temperature. Upon completion (monitored by TLC 5:1 HexEtOAc, purple spot in ninhydrin dip, $R_{\mathrm{f}}=0$ ) the reaction mixture was filtered to remove sieves and then stirred in an equal volume of water $(10 \mathrm{~mL})$ at room temperature for a further 30 minutes before being concentrated under reduced pressure and purified using column chromatography (EtOAc$\left.\mathrm{MeOH} 4: 1, R_{\mathrm{f}}=0.1\right)$ yielding $20(68 \mathrm{mg}, 60 \%)$ as an amorphous mass. ${ }^{1} \mathrm{H}$ NMR $\left(\mathrm{CDCl}_{3}\right) \delta: 0.15,0.18(2 \mathrm{~s}, 6 \mathrm{H}$, $\left.\mathrm{Si}\left(\mathrm{CH}_{3}\right)_{2}\right), 0.88\left(\mathrm{~s}, 9 \mathrm{H}, \mathrm{SiC}\left(\mathrm{CH}_{3}\right)_{3}\right), 0.91,1.11(\mathrm{~s}, 3 \mathrm{H}$, $\left.\mathrm{C}\left(\mathrm{CH}_{3}\right)_{2}\right), 1.80\left(\mathrm{dd}, 1 \mathrm{H}, J_{3 \mathrm{ax}, 3 \mathrm{eq}}=12.9 \mathrm{~Hz}, J_{3 \mathrm{ax}, 4}=11.4 \mathrm{~Hz}, \mathrm{H}-\right.$ $\left.3_{\mathrm{ax}}\right), 1.93\left(\mathrm{~s}, 3 \mathrm{H}, \mathrm{NHOCH}_{3}\right), 2.00\left(\mathrm{dd}, 1 \mathrm{H}, J_{3 \mathrm{eq}, 3 \mathrm{ax}}=12.9 \mathrm{~Hz}\right.$, $\left.J_{3 \text { eq }, 4}=4.5 \mathrm{~Hz}, \mathrm{H}-3_{\text {eq }}\right), 3.17\left(\mathrm{~s}, 3 \mathrm{H}, \mathrm{OCH}_{3}\right), 3.22\left(\mathrm{dd}, 1 \mathrm{H}, J_{6,5}=\right.$ $\left.1.2 \mathrm{~Hz}, J_{6,7}=9.9 \mathrm{~Hz}, \mathrm{H}-6\right), 3.40\left(\mathrm{dd}, 1 \mathrm{H}, J_{9,9^{\prime}}=9.3 \mathrm{~Hz}, J_{9,8}=\right.$ $6.0 \mathrm{~Hz}, \mathrm{H}-9), 3.70\left(\mathrm{~s}, 3 \mathrm{H}, \mathrm{CO}_{2} \mathrm{CH}_{3}\right), 4.08\left(\mathrm{dd}, 1 \mathrm{H}, J_{9}, 9=9.3\right.$ $\mathrm{Hz}, J_{9}, 8=6.0 \mathrm{~Hz}, \mathrm{H}-9^{\prime}$ ), 4.15 (br. s, $1 \mathrm{H}, J_{5,4}=3.0 \mathrm{~Hz}, \mathrm{H}-5$ ), $4.34\left(\mathrm{ddd}, 1 \mathrm{H}, J_{7,8}=1.2 \mathrm{~Hz}, J_{7,6}=J_{7,7 \mathrm{NHAc}}=9.9 \mathrm{~Hz}, \mathrm{H}-7\right.$ ), 4.45-4.53 (m, $2 \mathrm{H}, \mathrm{H}-8 / \mathrm{H}-4), 5.88$ (d, $1 \mathrm{H}, J_{7 \mathrm{NHAc}, 7}=9.9 \mathrm{~Hz}, 7-$ NHAc). IR: $2105 \mathrm{~cm}^{-1}\left(5-\mathrm{N}_{3}\right)$. ES-MS: $m / z=539.2[\mathrm{M}+$ $\mathrm{Na}]^{+}$. 
Methyl (methyl 5,7-di-acetamido-4-O-(tert-butyldimethylsilyl)-3,5,7-tri-deoxy-8,9-O-isopropylidene-Lglycero- $\beta$-L-manno-non-2-ulopyranosid)onate (21). To a solution of bis-azide $18(610 \mathrm{mg}, 1.25 \mathrm{mmol})$ in methanol at room temperature was added $p$-toluenesulphonic acid monohydrate (5\% mol. eq.) and $\mathrm{Pd}(\mathrm{OH})_{2} / \mathrm{C} 20 \%$ wt. $(20 \%$ by mass). The resulting reaction mixture was degased and the flask filled with $\mathrm{H}_{2}$ gas, after which the reaction was run at room temperature and pressure for 4 hours under a hydrogen atmosphere. The reaction mixture was filtered through Celite concentrated under reduced pressure with the resulting crystalline solid being taken up in acetic anhydride $(5 \mathrm{~mL})$ to which pyridine $(10 \mathrm{~mL})$ and DMAP $(20 \mathrm{mg})$ were added. The reaction mixture was stirred at room temperature under $\mathrm{N}_{2(\mathrm{~g})}$ for 16 hours, before being concentrated under reduced pressure taken up in EtOAc $(50 \mathrm{~mL})$ and washed with ice-cold dilute aqueous $\mathrm{HCl}(1 \mathrm{M}, 30 \mathrm{~mL})$ and water $(30 \mathrm{~mL})$. The organic phase was dried $\left(\mathrm{Na}_{2} \mathrm{SO}_{4}\right)$ and concentrated before being purified using column chromatography (EtOAc/MeOH (4:1), $\mathrm{R}_{\mathrm{f}}$ $=0.3$ ) yielding the bis-acetamide 21 (530 mg, 80\% over two steps) as an white crystalline solid. ${ }^{1} \mathrm{H} \mathrm{NMR}\left(\mathrm{CDCl}_{3}\right) \delta: 0.05$ (d, $\left.6 \mathrm{H}, \mathrm{Si}\left(\mathrm{CH}_{3}\right)_{2}\right), 0.82$ (s, $\left.9 \mathrm{H}, \mathrm{SiC}\left(\mathrm{CH}_{3}\right)_{3}\right), 1.25,1.37$ (s, $3 \mathrm{H}$, $\left.\mathrm{C}\left(\mathrm{CH}_{3}\right)_{2}\right), 1.60\left(\mathrm{dd}, 1 \mathrm{H}, J_{3 \mathrm{ax}, 3 \mathrm{eq}}=13.5 \mathrm{~Hz}, J_{3 \mathrm{ax}, 4}=10.4 \mathrm{~Hz}, \mathrm{H}-\right.$ $\left.3_{\mathrm{ax}}\right), 1.92,1.95\left(\mathrm{~s}, 3 \mathrm{H}, \mathrm{NHOCH}_{3}\right), 2.05\left(\mathrm{dd}, 1 \mathrm{H}, J_{3 \mathrm{eq}, 3 \mathrm{ax}}=13.5\right.$ $\left.\mathrm{Hz}, J_{3 \mathrm{eq}, 4}=5.1 \mathrm{~Hz}, \mathrm{H}-3_{\mathrm{eq}}\right), 3.23\left(\mathrm{~s}, 3 \mathrm{H}, \mathrm{OCH}_{3}\right), 3.52(\mathrm{dd}, 1 \mathrm{H}$, $J_{9,9}=8.4 \mathrm{~Hz}, J_{9^{\prime}, 8}=7.5 \mathrm{~Hz}, \mathrm{H}-9$ '), 3.79 (s, $\left.3 \mathrm{H}, \mathrm{CO}_{2} \mathrm{CH}_{3}\right), 3.92$ $\left(\mathrm{dd}, 1 \mathrm{H}, J_{6,5}=2.1 \mathrm{~Hz}, J_{6,7}=10.5 \mathrm{~Hz}, \mathrm{H}-6\right), 3.97$ (dd, $1 \mathrm{H}, J_{9,9}$, $\left.=8.4 \mathrm{~Hz}, J_{9,8}=6.9 \mathrm{~Hz}, \mathrm{H}-9\right), 4.12\left(\mathrm{ddd}, 1 \mathrm{H}, J_{4,5}=4.5 \mathrm{~Hz}, J_{4,3 \mathrm{ax}}\right.$ $\left.=10.4 \mathrm{~Hz}, J_{4,3 \mathrm{eq}}=5.1 \mathrm{~Hz}, \mathrm{H}-4\right), 4.29\left(\mathrm{ddd}, 1 \mathrm{H}, J_{7,8}=1.5 \mathrm{~Hz}\right.$, $\left.J_{7,6}=J_{7,7 \mathrm{NHAc}}=10.5 \mathrm{~Hz}, \mathrm{H}-7\right), 4.38\left(\mathrm{ddd}, 1 \mathrm{H}, J_{5,4}=4.5 \mathrm{~Hz}, J_{5,6}\right.$ $\left.=2.1 \mathrm{~Hz}, J_{5,5 \mathrm{NHAc}}=10.5 \mathrm{~Hz}, \mathrm{H}-5\right), 4.52\left(\mathrm{ddd}, 1 \mathrm{H}, J_{8,9}=6.9 \mathrm{~Hz}\right.$, $\left.J_{8,9}=7.5 \mathrm{~Hz}, J_{8,7}=1.5 \mathrm{~Hz}, \mathrm{H}-8\right), 5.46\left(\mathrm{~d}, 1 \mathrm{H}, J_{7 \mathrm{NHAc}, 7}=10.5\right.$ $\mathrm{Hz}, 7-\mathrm{N} H A \mathrm{c}), 5.55$ (d, $\left.1 \mathrm{H}, J_{5 \mathrm{~N} H \mathrm{Ac}, 5}=10.5 \mathrm{~Hz}, 5-\mathrm{N} H A \mathrm{c}\right) .{ }^{13} \mathrm{C}$ NMR $\left(\mathrm{CDCl}_{3}\right) \delta$ : $\left.-4.9 \mathrm{Si}\left(\mathrm{CH}_{3}\right)_{2}\right), 17.9\left(\mathrm{SiC}\left(\mathrm{CH}_{3}\right)_{3}\right), 23.2,23.3$ (2 $\left.\mathrm{NHCOCH}_{3}\right), 24.7\left(\mathrm{C}\left(\mathrm{CH}_{3}\right)_{2}\right), 25.5 \quad\left(\mathrm{SiC}\left(\mathrm{CH}_{3}\right)_{3}\right), \quad 26.2$ $\left(\mathrm{C}\left(\mathrm{CH}_{3}\right)_{2}\right), 36.6(\mathrm{C}-3), 47.7(\mathrm{C}-5), 48.0(\mathrm{C}-7), 51.1\left(\mathrm{OCH}_{3}\right)$, $52.6\left(\mathrm{CO}_{2} \mathrm{CH}_{3}\right), 65.2(\mathrm{C}-4), 65.6(\mathrm{C}-9), 70.5(\mathrm{C}-6), 73.6(\mathrm{C}-8)$, $99.3(\mathrm{C}-2), \quad 108.6 \quad\left(\mathrm{C}\left(\mathrm{CH}_{3}\right)_{2}\right), \quad 168.5 \quad\left(\mathrm{CO}_{2} \mathrm{CH}_{3}\right), \quad 170.2$ $\left(\mathrm{NHCOCH}_{3}\right), 170.3\left(\mathrm{NHCOCH}_{3}\right)$. ES-MS: $m / z=555.1[\mathrm{M}+$ $\mathrm{Na}]^{+}$. HRMS: $\left(\mathrm{C}_{24} \mathrm{H}_{44} \mathrm{~N}_{2} \mathrm{O}_{9} \mathrm{SiNa}\right)$ : Calculated: 555.270828; found: 555.269614

Methyl (methyl 5,7-di-acetamido-3,5,7-tri-deoxy-Lglycero- $\beta$-L-manno-non-2-ulopyranosid)onate

Trifluoroacetic acid $(0.23 \mathrm{~mL}, 3 \mathrm{mmol})$ was added to a stirred solution of 21 (530 mg, $1.0 \mathrm{mmol}$ ) in a mixture of THF and water $(4: 1)$ at $0^{\circ} \mathrm{C}$. The resulting reaction mixture was allowed to warm to room temperature and stirred for 48 hours before being neutralised with concentrated ammonia and concentrated under reduced pressure and chromatographed on silica gel (EtOAc/MeOH (4:1), $\left.\mathrm{R}_{\mathrm{f}}=0.25\right)$ yielding the triol 22 (302 mg, $80 \%)$ as an white amorphous mass. ${ }^{1} \mathrm{H} \mathrm{NMR}\left(\mathrm{CD}_{3} \mathrm{CN}\right) \delta: 1.63$ $\left(\mathrm{dd}, 1 \mathrm{H}, J_{3 \mathrm{ax}, 3 \mathrm{eq}}=12.3 \mathrm{~Hz}, J_{3 \mathrm{ax}, 4}=12.0 \mathrm{~Hz}, \mathrm{H}-3_{\mathrm{ax}}\right), 1.86,1.88$ $\left(\mathrm{s}, 3 \mathrm{H}, \mathrm{NHOCH}_{3}\right), 1.99\left(\mathrm{dd}, 1 \mathrm{H}, J_{3 \mathrm{eq}, 3 \mathrm{ax}}=12.3 \mathrm{~Hz}, J_{3 \mathrm{eq}, 4}=4.2\right.$ Hz, H-3 eq $), 3.21$ (s, 3 H, OCH $H_{3}$ ), 3.32 (m, 2 H, H-9/H-9'), 3.75 (s, $3 \mathrm{H}, \mathrm{CO}_{2} \mathrm{CH}_{3}$ ), 3.93 (br. dd, $1 \mathrm{H}, J_{8,9}=J_{8,9}=7.5 \mathrm{~Hz}, \mathrm{H}-8$ ), 4.06 (br. m, $3 \mathrm{H}, \mathrm{H}-4 / \mathrm{H}-6 / \mathrm{H}-7$ ), 4.34 (br. dd, $1 \mathrm{H}, J_{5,4}=3.9 \mathrm{~Hz}$,
$\left.J_{5,5 \mathrm{NHAc}}=9.9 \mathrm{~Hz}, \mathrm{H}-5\right), 6.49\left(\mathrm{~d}, 1 \mathrm{H}, J_{5 \mathrm{NHAc}, 5}=9.9 \mathrm{~Hz}, 5-\right.$ $\mathrm{N} H A \mathrm{c}), 6.60\left(\mathrm{~d}, 1 \mathrm{H}, J_{7 \mathrm{NHAc}, 7}=9.9 \mathrm{~Hz}, 7-\mathrm{N} H \mathrm{Ac}\right) .{ }^{13} \mathrm{C} \mathrm{NMR}$

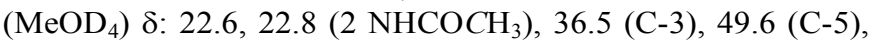
$50.7(\mathrm{C}-7), 51.9\left(\mathrm{OCH}_{3}\right), 53.2\left(\mathrm{CO}_{2} \mathrm{CH}_{3}\right), 64.8(\mathrm{C}-9), 66.2(\mathrm{C}-$ 4), 70.1 (C-6), 70.3 (C-8), 100.6 (C-2), $170.7\left(\mathrm{CO}_{2} \mathrm{CH}_{3}\right), 173.8$, $174.5\left(2 \mathrm{NHCOCH}_{3}\right)$. ES-MS: $m / z=401.1[\mathrm{M}+\mathrm{Na}]^{+}$

Methyl (methyl 5,7-di-acetamido-9-iodo-3,5,7,9-tetradeoxy-L-glycero- $\beta$-L-manno-non-2-ulopyranosid)onate (23). Triphenylphosphine $(315 \mathrm{mg}, 1.2 \mathrm{mmol})$, Imidazole $(110 \mathrm{mg}$, $1.6 \mathrm{mmol}$ ) and Iodine (305 $\mathrm{mg}, 1.2 \mathrm{mmol})$ were added to a stirred solution of the triol $22(302 \mathrm{mg}, 0.8 \mathrm{mmol})$ in THF (10 $\mathrm{mL})$ under $\operatorname{Argon}_{(\mathrm{g})}$ at room temperature. The mixture was heated under reflux for 2 hours, before being allowed to cool to room temperature. A stoichiometric amount of $\mathrm{Na}_{2} \mathrm{~S}_{2} \mathrm{O}_{5}$ dissolved in methanol $(10 \mathrm{~mL})$ was added, and then the now clear reaction mixture was absorbed onto non-flash silica gel and concentrated to dryness. The residue was purified on silica gel chromatography (EtOAc/MeOH (4:1), $\left.\mathrm{R}_{\mathrm{f}}=0.4\right)$ yielding the 9-iodo-derivative $\mathbf{2 3}$ (280 $\mathrm{mg}, 71 \%)$ as an amorphous mass. ${ }^{1} \mathrm{H} \mathrm{NMR}\left(\mathrm{CD}_{3} \mathrm{CN}\right) \delta: 1.63\left(\mathrm{dd}, 1 \mathrm{H}, J_{3 \mathrm{ax}, 3 \mathrm{eq}}=12.9 \mathrm{~Hz}, J_{3 \mathrm{ax}, 4}=\right.$ $\left.12.3 \mathrm{~Hz}, \mathrm{H}-3_{\mathrm{ax}}\right), 1.88,1.92$ (s, $3 \mathrm{H}, \mathrm{NHOCH}_{3}$ ), 2.01 (dd, $1 \mathrm{H}$, $\left.J_{3 \mathrm{eq}, 3 \mathrm{ax}}=12.9 \mathrm{~Hz}, J_{3 \mathrm{eq}, 4}=4.8 \mathrm{~Hz}, \mathrm{H}-3_{\mathrm{eq}}\right), 3.20\left(\mathrm{~s}, 3 \mathrm{H}, \mathrm{OCH}_{3}\right)$, 3.25 (br. m, 2 H, H-9/H-9'), 3.75 (s, 3 H, $\mathrm{CO}_{2} \mathrm{CH}_{3}$ ), 4.06 (br. m, 3 H, H-6/H-4/H-8), 4.25 (br. s, 1 H, H-5), 4.29 (br. s, H-7), 6.69 $\left(\mathrm{d}, 1 \mathrm{H}, J_{5 \mathrm{NHAc}, 5}=9.9 \mathrm{~Hz}, 5-\mathrm{N} H A \mathrm{c}\right), 6.85\left(\mathrm{~d}, 1 \mathrm{H}, J_{7 \mathrm{NHAc}, 7}=9.9\right.$ $\mathrm{Hz}, 7-\mathrm{NHAc}) .{ }^{13} \mathrm{C} \mathrm{NMR}\left(\mathrm{MeOD}_{4}\right)$ 8: 9.4 (C-9), 22.7, 22.9 (2 $\left.\mathrm{NHCOCH}_{3}\right), 36.4(\mathrm{C}-3), 52.0(\mathrm{C}-5), 52.2\left(\mathrm{CO}_{2} \mathrm{CH}_{3}\right), 52.3(\mathrm{C}-$ 7), $53.3\left(\mathrm{OCH}_{3}\right), 66.2(\mathrm{C}-4), 70.9(\mathrm{C}-6), 71.5(\mathrm{C}-8), 100.5(\mathrm{C}-2)$, $170.7\left(\mathrm{CO}_{2} \mathrm{CH}_{3}\right), 173.4,174.6\left(2 \mathrm{NHCOCH}_{3}\right)$. ES-MS: $m / z=$ $511.1[\mathrm{M}+\mathrm{Na}]^{+}$

Methyl (methyl 5,7-di-acetamido-3,5,7,9-tetra-deoxy-Lglycero- $\boldsymbol{\beta}$-L-manno-non-2-ulopyranosid)onate (24). $\mathrm{Pd}(\mathrm{OH})_{2} / \mathrm{C}(20 \%$ wt.) (20\% by mass) and disopropylethylamine $(0.02 \mathrm{~mL}, 0.1 \mathrm{mmol})$ were added to a solution of $23(280 \mathrm{mg}$, $0.57 \mathrm{mmol})$ in methanol $(5 \mathrm{~mL})$ under $\operatorname{Ar}_{(\mathrm{g})}$ at room temperature. The resulting reaction mixture was degased and the flask filled with $\mathrm{H}_{2}$ gas, after which the reaction was run at room temperature and pressure for 12 hours under a hydrogen atmosphere. The reaction mixture was filtered through Celite and concentrated under reduced pressure. The resulting residue was purified using column chromatography (EtOAc/MeOH $\left.(4: 1), \mathrm{R}_{\mathrm{f}}=0.3\right)$ yielding the 8-epi-Pse derivative $24(200 \mathrm{mg}$, $96 \%)$ as a white solid. ${ }^{1} \mathrm{H}$ NMR $\left(\mathrm{CD}_{3} \mathrm{CN}\right) \delta: 1.06\left(\mathrm{~d}, 3 \mathrm{H}, J_{9,8}\right.$ $=6.3 \mathrm{~Hz}, \mathrm{H}-9), 1.62\left(\mathrm{dd}, 1 \mathrm{H}, J_{3 \mathrm{ax}, 3 \mathrm{eq}}=13.2 \mathrm{~Hz}, J_{3 \mathrm{ax}, 4}=12.0\right.$ $\left.\mathrm{Hz}, \mathrm{H}-3_{\mathrm{ax}}\right), 1.86,1.87$ (s, $\left.3 \mathrm{H}, \mathrm{NHOCH}_{3}\right), 2.01$ (dd, $1 \mathrm{H}, J_{3 \mathrm{eq}, 3 \mathrm{ax}}$ $\left.=13.2 \mathrm{~Hz}, J_{3 \mathrm{eq}, 4}=5.1 \mathrm{~Hz}, \quad \mathrm{H}-3_{\text {eq }}\right), 3.20\left(\mathrm{~s}, 3 \mathrm{H}, \mathrm{OCH}_{3}\right), 3.75$ (s, $3 \mathrm{H}, \mathrm{CO}_{2} \mathrm{CH}_{3}$ ), 3.83 (br. dd, $1 \mathrm{H}, J_{7,8}=1.5 \mathrm{~Hz}, J_{7,7 \mathrm{~N} H \mathrm{Ac}}=9.6$ Hz, H-7), 4.02 (br. m, 3 H, H-6/H-4/H-8), 4.24 (br. m, 1 H, H5), $6.35\left(\mathrm{~d}, 1 \mathrm{H}, J_{7 \mathrm{NHAc}, 7}=9.6 \mathrm{~Hz}, 7-\mathrm{N} H \mathrm{Ac}\right), 6.47(\mathrm{~d}, 1 \mathrm{H}$, $\left.J_{5 \mathrm{NHAc}, 5}=9.6 \mathrm{~Hz}, 5-\mathrm{NHAc}\right) .{ }^{13} \mathrm{C} \mathrm{NMR}\left(\mathrm{CD}_{3} \mathrm{CN}\right) \delta: 20.9$ (C-9), 23.2, $23.3\left(2 \mathrm{NHCOCH}_{3}\right), 36.6(\mathrm{C}-3), 49.4(\mathrm{C}-5), 51.7\left(\mathrm{OCH}_{3}\right)$, $53.0\left(\mathrm{CO}_{2} \mathrm{CH}_{3}\right), 54.2(\mathrm{C}-7), 65.5(\mathrm{C}-8), 66.7$ (C-4), $70.5(\mathrm{C}-6)$, $100.2(\mathrm{C}-2), 170.7\left(\mathrm{CO}_{2} \mathrm{CH}_{3}\right), 171.3,173.2\left(2 \mathrm{NHCOCH}_{3}\right)$. ES-MS: $m / z=385.1[\mathrm{M}+\mathrm{Na}]^{+}$.

\section{Acknowledgements}


We thank Griffith University for a PhD Scholarship to MZ, the School of Pharmacy (Griffith University) and the School of Environment (Griffith University) for financial support to $\mathrm{JW}$ and JC, respectively.

\section{Notes and references}

a Institute for Glycomics, Griffith University Gold Coast Campus, Southport, Queensland, 4222, Australia.

${ }^{b}$ Current Address: School of Pharmacy, Griffith University Gold Coast Campus, Southport, Queensland, 4222, Australia.

${ }^{c}$ Current Address: School of Chemistry, University of Sydney, NSW, Australia.

Electronic Supplementary Information (ESI) available: [copies of NMR spectra for key compounds prepared are provided]. See DOI: 10.1039/b000000x/

1. C. Traving and R. Schauer, Cellular and Molecular Life Sciences, 1998, 54, 1330-1349.

2. A. Varki, A., Glycobiology, 1992, 2, 25-40.

3. T. Angata and A. Varki, Chemical Reviews, 2002, 102, 439-469.

4. X. Chen and A. Varki, ACS Chem. Biol., 2010, 5, 163-176.

5. L. Kandiba and J. Eichler, FEMS Microbiol. Lett., 2013, 345, 110120.

6. R. Schauer, Curr. Opin. Struct. Biol., 2009, 19, 507-514.

7. P.-H. Wang, J. Cancer Molecules, 2005, 1, 73-81.

8. A. Varki, Trends Mol. Med., 2008, 14, 351-360.

9. Y. Knirel, S. Shevelev, and A. Perepelov, Mendeleev Commun., 2011, 21, 173-182.

10. M. Zunk and M.J. Kiefel, $R S C A d v$., DOI: $10.1039 / \mathrm{c} 3 \mathrm{ra} 44924 \mathrm{f}$

11. Y. Knirel, E. Vinogradov, V. L'vov, N. Kocharova, A. Shashkov, B. Dmitriev, and N. Kochetkov, Carbohydr. Res., 1984, 133, C5-C8.

12. Y.A. Knirel, J.H. Helbig and U. Zähringer, Carbohydr. Res., 1996, 283, 129-139.

13. S.M. Logan, J.P.M. Hui, E. Vinogradov, A.J. Aubry, J.E. Melanson, J.F. Kelly, H. Nothaft and E.C. Soo, FEBS J., 2009, 276, 1014-1023.

14. D.J. McNally, A.J. Aubry, J.P.M. Hui, N.H. Khieu, D. Whitfield, C.P. Ewing, P. Guerry, J.-R. Brisson, S.M. Logan and E.C. Soo, J. Biol. Chem., 2007, 282, 14463-14475.

15. Y.E. Tsvetkov, A.S. Shashkov, Y.A. Knirel and U. Zähringer, Carbohydr. Res., 2001, 331, 233-237.

16. Y.E. Tsvetkov, A.S. Shashkov, Y.A. Knirel and U. Zähringer, Carbohydr. Res., 2001, 335, 221-243.

17. P. Edebrink, P.-E. Jansson, J. Bøgwald and J. Hoffman, Carbohydr. Res., 1996, 287, 225-245.

18. N. Hashii, Y. Isshiki, T. Iguchi, K. Hisatsune and S. Kondo, Carbohydr. Res., 2003, 338, 1055-1062.

19. N. Hashii, Y. Isshiki, T. Iguchi and S. Kondo, Carbohydr. Res., 2003 , 338, 1063-1071.

20. S.R. Haseley and S.G. Wilkinson, Eur. J. Biochem., 1997, 250, 617623.

21. X. Li, A.V. Perepelov, Q. Wang, S.N. Senchenkova, B. Liu, S.D. Shevelev, X. Guo, A.S. Shashkov, W. Chen, L. Wang and Y.A. Knirel, Carbohydr. Res., 2010, 345, 1581-1587.

22. Y.A. Knirel, S.N. Senchenkova, A.S. Shashkov, S.D. Shevelev, A.V. Perepelov, L. Bin, L. Feng and L. Wang, Adv. Sci. Lett., 2009, 2, 384-387.
23. A.V. Perepelov, B. Liu, S.N. Senchenkova, A.S. Shashkov, S.D. Shevelev, L. Feng, L. Wang and Y.A. Knirel, Biochemistry (Moscow), 2010, 75, 19-24.

24. F. Liu, A.J. Aubry, I.C. Schoenhofen, S.M. Logan and M.E. Tanner, ChemBioChem, 2009, 10, 1317-1320.

25. M. Schirm, E.C. Soo, A.J. Aubry, J. Austin, P. Thibault and S.M. Logan, Molecular Microbiology, 2003, 48, 1579-1592.

26. S.M. Logan, Microbiology, 2006, 152, 1249-1262.

27. P. Thibault, S.M. Logan, J.F. Kelly, J-R. Brisson, C.P Ewing, T.J. Trust and P. Guerry, J. Biol. Chem., 2001, 276, 34862-34870.

28. S.M. Logan, J.F. Kelly, P. Thibault, C.P. Ewing and P. Guerry, Molecular Microbiology, 2002, 46, 587-597.

29. J.L. Parker, M.J. Day-Williams, J.M. Tomas, G.P. Stafford and J.G. Shaw, MicrobiologyOpen, 2012, 1, 149-160.

30. M. Zilbauer, N. Dorrell, B.W. Wren and M. Bajaj-Elliott, Trans. Royal Soc. Trop. Med. Hygiene, 2008, 102, 123-129.

31. Y.A. Knirel, A.S. Shashkov, Y.E. Tsvetkov, P-E. Jansson, and U. Zähringer, Adv. Carb. Chem. Biochem., 2003, 58, 371-417.

32. I.C. Schoenhofen, D.J. McNally, J.-R. Brisson and S.M. Logan, Glycobiology, 2006, 16, 8C-14C.

33. W.K. Chou, S. Dick, W.W. Wakarchuk and M.E. Tanner, J. Biol. Chem., 2005, 280, 35922-35928.

34. Y.J. Lee, A. Kubota, A. Ishiwata and Y. Ito, Tetrahedron Lett., 2011, 52, 418-421.

35. At the commencement of this project we purchased $100 \mathrm{~g}$ of KDN from Codexis, however this company no longer exists. To the best of our knowledge preparative scale quantities of $\mathrm{KDN}$ are no longer commercially available.

36. M. Nakamura, H. Takayanagi, K. Furuhata and H. Ogura, Chem \& Pharmac. Bull, 1992, 40, 879-885.

37. W. Fitz, J.-R. Schwark and C.-H. Wong, J. Org. Chem., 1995, 60, 3663-3670.

38. Y. Li, H. Yu, H. Cao, K. Lau, S. Muthana, V.K. Tiwari, B. Son and X. Chen, Appl. Microbiol. Biotechnol., 2008, 79, 963-970.

39. For a recent efficient synthesis of KDN see: D. Crich and C. Navuluri, Org. Lett., 2011, 13, 6288-6291.

40. E. Schreiner and E. Zbiral, Liebigs Ann. Chem., 1990, 581-586.

41. C. Navuluri and D. Crich, Angew. Chem. Int. Ed., 2013, 52, 1133911342.

42. D.T. Glatzhofer, R.R. Roy and K.N. Cossey, Org. Lett., 2002, 4, 2349-2352.

43. One of the minor components we isolated from this reaction was identified as the $N$-nitroso analogue of compound 7 (shown in Scheme 2), primarily due to the presence of a 3 proton singlet in the ${ }^{1} \mathrm{H} \mathrm{nmr} \mathrm{spectrum}$ at $\delta 2.67 \mathrm{ppm}$. We never obtained enough of this minor component to fully characterise it.

44. E.H. White, J. Am. Chem. Soc., 1955, 77, 6008.

45. E.H. White, J. Am. Chem. Soc., 1955, 77, 6011.

46. E.H. White, J. Am. Chem. Soc., 1955, 77, 6014.

47. R. Kuhn, P. Lutz and D.L. MacDonald, Chem. Ber., 1966, 99, 611617.

48. S. David, A. Malleron and B. Cavayé, Carbohydr. Res., 1994, 260, 233-241.

49. Preliminary crystallographic analysis of $\mathbf{1 9}$ was carried out by Prof Peter Healy, Griffith University, Brisbane, Australia. Unfortunately the crystals contained four molecules in the asymmetric unit that 
could not be resolved to publication standard, but the data obtained is sufficiently well resolved to support the proposed structure. 